\title{
Potential of olfactory ensheathing cells for cell-based therapy in spinal cord injury
}

\author{
Christine Radtke, MD, PhD; ${ }^{1-3}$ Masanori Sasaki, MD, PhD; ${ }^{1-2}$ Karen L. Lankford, PhD; ${ }^{1-2}$ Peter M. Vogt, MD, \\ PhD; ${ }^{3}$ Jeffery D. Kocsis, PhD ${ }^{1-2 *}$ \\ ${ }^{1}$ Neuroscience Research Center, Department of Veterans Affairs Connecticut Healthcare System, West Haven, CT; \\ ${ }^{2}$ Department of Neurology and Center for Neuroscience and Regeneration Research, Yale University School of \\ Medicine, New Haven, CT; ${ }^{3}$ Department of Plastic, Hand, and Reconstructive Surgery, Hannover Medical School, \\ Hannover, Germany
}

\begin{abstract}
Contusive spinal cord injury (SCI) results in a complex lesion that includes cellular and axonal loss, microglia and macrophage activation, and demyelination. These changes result in permanent neurological deficits in people with SCI and in high financial costs to society. Unlike the peripheral nervous system (PNS), in which axonal regeneration can occur, axonal regeneration in the central nervous system (CNS) is extremely limited. This limited regeneration is thought to result from a lack of a permissive environment and from active inhibitory molecules that are present in the CNS but minimal in the PNS. Currently, cell transplantation approaches are among several experimental strategies being investigated for the treatment of SCI. In the olfactory system, a specialized glial cell called the olfactory ensheathing cell (OEC) has been shown to improve functional outcome when transplanted into rodents with SCI, and clinical studies transplanting OECs into patients with SCI are ongoing in China, Portugal, and other sites. Yet, a number of controversial issues related to OEC biology and transplantation must be addressed to understand the rationale and expectations for OEC cell therapy approaches in SCI. This review provides information on these issues for spinal cord medicine clinicians.
\end{abstract}

Key words: axons, cell-based therapy, cell transplantation, central nervous system, functional recovery, neuroprotection, olfactory ensheathing cell, rehabilitation, remyelination, spinal cord injury.

\section{INTRODUCTION}

More than 11,000 traumatic spinal cord injuries (SCIs) are estimated to occur in the United States each year [1]. Unfortunately, aside from good medical management, no generally accepted interventional therapies are available. While neurogenesis has long been thought to occur only during embryogenesis, recent advances in cell biology have identified progenitor cells for neurons and glia in the adult nervous system. These discoveries have given rise to the concept that a cell-based therapy

\footnotetext{
Abbreviations: BDNF = brain-derived neurotrophic factor, CNS = central nervous system, GFP = green fluorescent protein, GFP-OEC = olfactory ensheathing cell derived from GFP transgenic rats, $\mathrm{K}_{\mathrm{v}} 1$ = Shaker-type voltage-gated potassium channel, $\mathrm{M} 1=$ primary motor cortex, $\mathrm{Na}_{\mathrm{v}}=$ voltage-gated sodium channel, $\mathrm{NGF}=$ nerve growth factor, $\mathrm{OB}=$ olfactory bulb, $\mathrm{OEC}=$ olfactory ensheathing cell, $\mathrm{OM}=$ olfactory mucosa, $\mathrm{ONL}=$ outer nerve layer, ORN = olfactory receptor neuron, p75NGFR $=$ p75 NGF receptor, PNS = peripheral ner vous system, RMS = rostral migratory stream, $\mathrm{SCI}=$ spinal cord injury, SVZ = subventricular zone.

*Address all correspondence to Jeffery D. Kocsis, PhD; Neuroscience Research Center, Department of Veterans Affairs Connecticut Healthcare System, 950 Campbell Avenue, 127A, West Haven, CT 06516; 203-937-3802; fax: 203937-3801. Email: Jeffery.Kocsis@yale.edu

DOI: 10.1682/JRRD.2007.03.0049
} 
might be developed for patients with SCI (see Reier [2] for an overview). Unlike Parkinson's disease, where the rationale for transplantation therapy is to replace neurons that produce dopamine, a primary objective of spinal cord repair is to regenerate long axonal tracts and remyelinate axons. Thus, while neurons may die at the injury site, neurogenesis of these segmental neurons is considered less important than establishment of new functional axonal links to intact spinal cord circuits below and above the level of injury.

A number of myelinating cells and their precursors have been shown to remyelinate spinal cord axons after transplantation [3]. Neural progenitor cells, which can differentiate into neurons and glia, can be isolated from the adult mammalian dentate gyrus [4], the subventricular zone (SVZ) that lines the lateral ventricles [5-7], and the spinal cord [8] and have been used to remyelinate axons. Importantly, neural progenitor cells isolated from adult human brain can differentiate into neurons and glia [9-11]. Remyelination results when neural progenitors, prepared from biopsy of the SVZ under ultrasound guidance in the nonhuman primate, are transplanted into the demyelinated spinal cord of the same animal [12]. Moreover, neural precursor cells have been prepared from a number of peripheral tissues, such as bone marrow [13], skin, and peripheral blood [14], and active investigation of their potential therapeutic effects in central nervous system (CNS) repair is ongoing. A concern with multipotent "stem cells" is that upon transplantation, they might differentiate into ectopic tissues. For example, bone marrow-derived mesenchymal stem cells can potentially differentiate into cartilage when transplanted into the spinal cord. Clearly, establishing appropriate differentiation methods in vitro to prevent undesirable in vivo differentiation is essential when a cell type is being considered for clinical transplantation studies.

A unique cell within the olfactory system is a specialized glial cell called the olfactory ensheathing cell (OEC). The OEC has attracted much recent attention and is currently being used in clinical studies in patients with SCI. Within the nasal cavity (olfactory mucosa [OM]), olfactory receptor neurons (ORNs) are replaced by a resident population of stem cells [15]. The axons of the ORNs will regenerate through the olfactory nerve and enter the olfactory bulb (OB) of the CNS, where they will make new synaptic contacts [16-17]. Neurogenesis of the ORNs is unique, as is regeneration of peripheral axons that can successfully navigate entry into the CNS and establish appropriate functional circuits. Current thinking is that OECs serve as glial guides for the regeneration of ORN axons [18-20]. This guidance property of OECs led to the suggestion that isolation and transplantation of these cells could promote axonal regeneration in the injured spinal cord. The present review discusses the biology of the OEC, OEC transplantation studies in animal models of SCI and demyelination, and ongoing clinical studies in which OECs are being transplanted into patients with SCI.

\section{UNIQUE REGENERATIVE PROPERTIES WITHIN OLFACTORY SYSTEM}

Two important neurogenic zones are related to the olfactory system: the neural epithelium in the OM in the periphery and the SVZ in the CNS (Figure 1). ORNs are

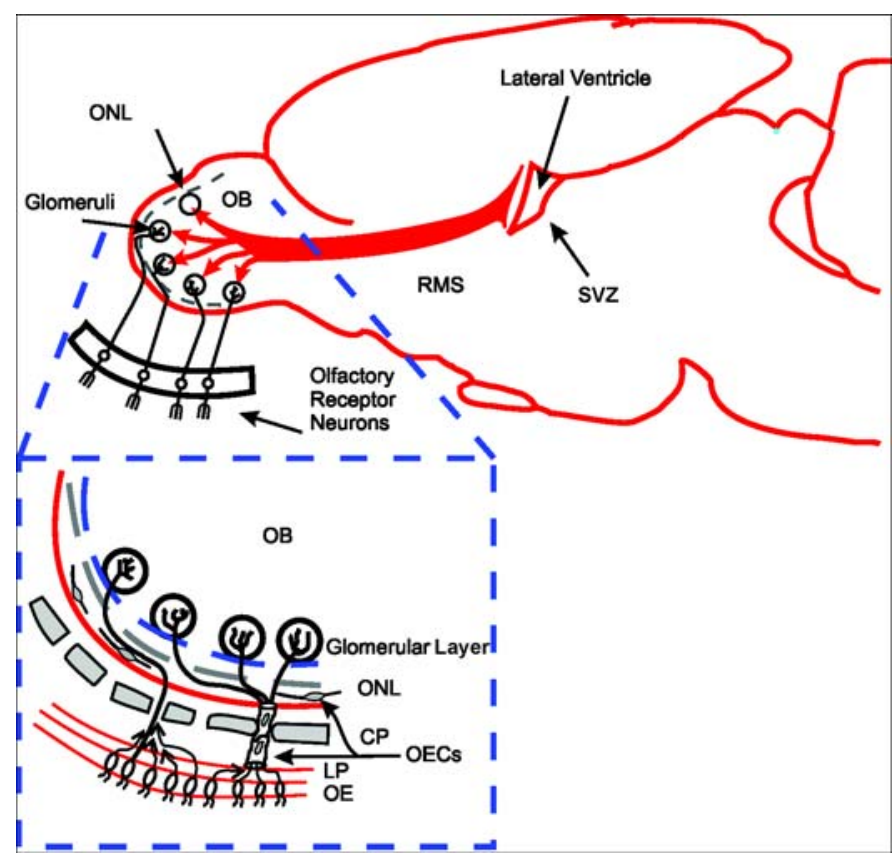

Figure 1.

Basic organization of olfactory system and two important neurogenic zones in adult: subventricular zone (SVZ) and olfactory epithelium (OE). Neural precursor cells in SVZ migrate to olfactory bulb (OB) through rostral migratory stream (RMS) in brain. New olfactory receptor neurons are generated in $\mathrm{OE}$ and issue axons that grow into $\mathrm{OB}$ to terminate in glomerular layer of $\mathrm{OB}$. These axons are nonmyelinated and grow through glial "tunnels" formed by olfactory ensheathing cells (OECs). OECs bridge periphery and central nervous system and are distributed in outer nerve layer (ONL) of OB. $\mathrm{CP}=$ cribriform plate, $\mathrm{LP}=$ lamina propria. 
continually replaced by a stem cell population in the OM, and neural precursor cells in the SVZ migrate through the rostral migratory stream (RMS) to the OB, where they differentiate into interneurons [21]. The cells that migrate from the SVZ through the RMS are neurogenic cells ("adult stem cells") that have been harvested for transplantation studies. The reason that neurogenesis is so prominent in the olfactory system is unknown. Given the importance of olfaction for mammalian survival and the potential damage to ORNs from noxious environmental influences, the neurogenic properties of the system may be conserved for survival of the species.

In the peripheral nerve, Schwann cells form basal lamina tubes (bands of Büngner) through which regenerating axons grow. Within the olfactory nerve, the OECs form cellular channels or tunnels through which large numbers of small-caliber nonmyelinated axons distribute through the olfactory nerve into the outer nerve layer (ONL) of the OB and extend into the olfactory glomeruli, where they make synapses (Figure 1) [19]. OECs in the ONL are thought to provide a permissive environment that allows entry of ORN axons into the CNS. OECs' unique property of bridging the peripheral nervous system (PNS) and CNS and providing a channel for peripheral axonal growth into the CNS led to the suggestion that these cells may be therapeutic if transplanted into transected spinal cord tracts [18-19].

\section{ISOLATION OF OLFACTORY ENSHEATHING CELLS FROM OLFACTORY BULB AND OLFACTORY MUCOSA}

OECs develop from the olfactory placode and subsequently migrate into the olfactory nerve and OB. This developmental origin contrasts to that of Schwann cells, which arise from the neural crest. From their origin in the $\mathrm{OM}$ to their termination in the glomeruli of the $\mathrm{OB}$, the nonmyelinated olfactory nerves are associated with OECs, which surround large numbers of contiguous axons [19,22-24]. The olfactory nerve and the ONL of the OB are enriched in OECs, which have p75 nerve growth-factor receptors (p75NGFRs).

Initial studies have transplanted OECs obtained from OBs into injured spinal cord and demonstrated functional improvement. OECs are present throughout the course of the olfactory nerves and can be harvested at the OM and the OB. Cultures of OECs from the OB [25-26] and the
OM have been described in a number of studies [27]. Lu and colleagues have demonstrated the reparative effects of mucosal-derived cells after intraspinal transplantation [28]. The majority of OECs used in studies on SCI regeneration have been from primary cultures obtained from the rat $\mathrm{OB}$ or OM [28-29].

Methods have been developed to purify OECs. OECs have been obtained from embryonic tissue [30], in which the nerve fiber layer is only loosely attached to the marginal zone of the primordial OB [31], thus reducing possible contamination by other OB cell types. Fluorescenceactivated cell sorting for O4-positive cells from neonatal tissue has been performed [32]. OEC selection from adult rats has also been performed with the use of immunopanning [33] or magnetic beads against p75NGFR [34]. These methods result in varying degrees of OEC purity and yield. Mixed cultures of OEC and highly purified OEC cultures have been extensively tested as possible therapeutic tools in experimental SCI research [35]. While some studies purified and maintained these cells in culture, other studies used acutely prepared cell suspensions from the OB, which were then transplanted into either SCI models [36] or demyelinated lesion models [37].

\section{TRANSPLANTATION OF OLFACTORY ENSHEATHING CELLS INTO EXPERIMENTAL DEMYELINATED SPINAL CORD LESIONS}

In the olfactory nerve, OECs surround large numbers of nonmyelinated axons and normally do not form myelin [38]. However, Franklin et al. first demonstrated that OECs derived from a cell line can form Schwann celllike myelin, which has the classic signet ring configuration [39]. Subsequently, remyelination by OEC transplants from a variety of species including humans has been reported [37,40-43]. OECs have also been shown to produce myelin when transplanted into the nonhuman primate spinal cord [42].

Green fluorescent protein (GFP)-OECs, or OECs prepared from GFP transgenic rats, were transplanted into a chemically induced demyelinating lesion in the rat dorsal funiculus (Figure 2). These cells have a reporter gene to express GFP in their cytoplasm for cell identification [43]. In the sagittal section of the spinal cord shown in Figure 2(a), the transplanted cells (green) are distributing within the demyelinated lesion. Demyelinated fibers from a spinal cord with a chemically induced demyelinated 


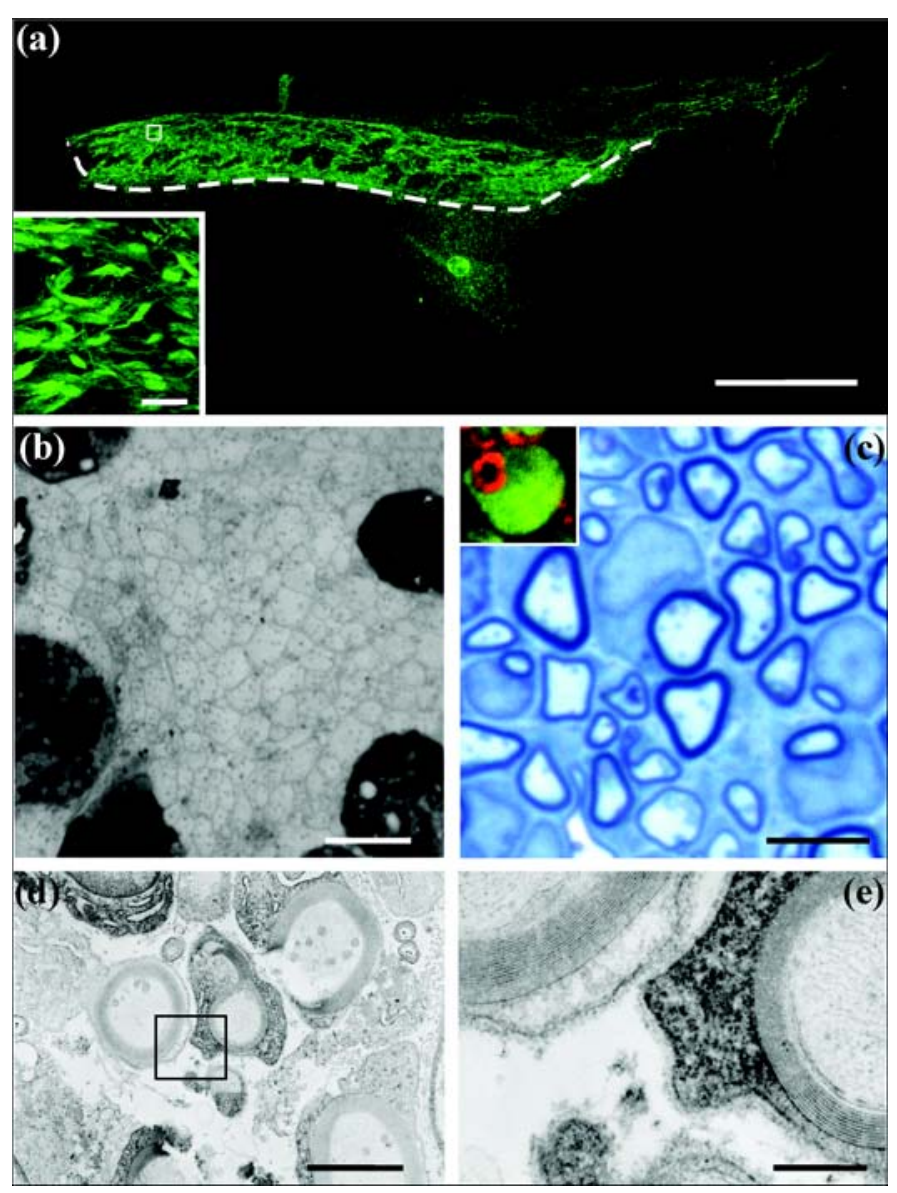

Figure 2.

Histological evidence that transplanted olfactory ensheathing cells (OECs) remyelinate central nervous system axons. (a) Sagittal frozen section through chemically demyelinated rat dorsal-column lesion illustrating distribution of transplanted green fluorescent protein (GFP)-expressing rat OECs. Transplanted cells are primarily confined to lesion site. Dashed line demarcates lesion boundary. Inset corresponds to boxed area in (a) and shows alignment of OECs with dorsal-column axons. (b) Demyelinated axons in spinal cord dorsal funiculus without OEC transplantation. Note large dark macrophages in addition to demyelinated axons. (c) Semithin coronal plastic section of spinal cord white matter 3 weeks after OEC transplantation showing peripheral-like myelinated axon profiles within lesion. Inset shows red PO-positive myelin rings associated with green transplanted cell, indicating that transplanted cells produce peripheral-like myelin protein. (d)-(e) Immunoelectron micrographs of GFP-OEC transplanted lesions stained with anti-GFP antibody showing that GFP donor cells produce compact myelin. Boxed area in (d) is magnified in (e). Note dense reaction product indicating GFP presence and basal lamina associated with myelinating axon on right. Scale bars: (a) $1 \mathrm{~mm}$, inset = $20 \mu \mathrm{m}$; (b) $10 \mu \mathrm{m}$; (c) $10 \mu \mathrm{m}$; (d) $2 \mu \mathrm{m}$; (e) $0.4 \mu \mathrm{m}$. Modified from Sasaki M, Lankford KL, Zemedkun M, Kocsis JD. Identified olfactory ensheathing cells transplanted into the transected dorsal funiculus bridge the lesion and form myelin. J Neurosci. 2004;24(39):8485-93. [PMID: 15456822] lesion without transplantation are shown in Figure 2(b). When OECs were transplanted into the demyelinated lesion, numerous myelinated axons were observed 3 weeks later (Figure 2(c)). Immunoelectron microscopy, in which an antibody for GFP is used to identify the transplanted cells on the ultrastructural level (Figure 2(d)-(e)), clearly indicates that transplanted OECs can form myelin [44].

However, some investigators have argued that OECs are not the myelinating cells in the just-mentioned studies but that contaminating Schwann cells are responsible for the remyelination [45]. These investigators suggest that OECs, but not Schwann cells, express calponin, a muscle fiber actin-binding protein [46], and that many cells in OEC culture preparations are p75-positive and calponinnegative, thus suggesting that OEC cultures were contaminated by Schwann cells. Franklin et al.'s study in which they used an OEC line and achieved remyelination provides a strong counterargument to the theory that Schwann-cell contamination accounts for remyelination by OECs [39]. A recent study demonstrated that calponin was present in the olfactory fibroblast meningeal cells but not in the adult OECs [47], thus strengthening the argument that OECs can form myelin.

An important aspect of remyelination is that it restores rapid impulse conduction. This restoration is achieved by the high resistance and low capacitance that myelin confers to the axonal membrane and by proper distribution of specific subtypes of sodium and potassium channels [48]. In myelinated axons, voltage-gated sodium channels $\left(\mathrm{Na}_{\mathrm{V}} \mathrm{s}\right)$ are aggregated in high density at nodes of Ranvier, while Shaker-type voltage-gated potassium channels $\left(\mathrm{K}_{\mathrm{v}} 1 \mathrm{~s}\right)$ are clustered within juxtaparanodal regions and separated from nodal $\mathrm{Na}_{\mathrm{v}} \mathrm{s}$ by septatelike paranodal junctions [49-51]. Of the seven $\mathrm{Na}_{\mathrm{v}}$ isoforms expressed in nervous tissue [52], $\mathrm{Na}_{\mathrm{v}} 1.6$ is the predominant $\mathrm{Na}_{\mathrm{v}}$ at mature nodes of Ranvier in both the PNS and CNS [5354], following a transition from $\mathrm{Na}_{\mathrm{v}} 1.2$, which is present along premyelinated axons and at immature nodes [53,55-57]. The clustering of $\mathrm{Na}_{\mathrm{v}} \mathrm{s}$ [58-59] and the transition from $\mathrm{Na}_{\mathrm{v}} 1.2$ to $\mathrm{Na}_{\mathrm{v}} 1.6[53,57]$ at nodes has been shown to critically depend on the axon interacting with myelinating glial cells, with both oligodendrocytes [60] and Schwann cells [61]. Thus, determining whether axons remyelinated by OECs respond by establishing appropriate mature nodal ion channel organization is critical.

We examined spinal cord dorsal funicular axons that were remyelinated by transplanted GFP-OECs to facilitate their identification. We demonstrated that GFP-OECs form compact myelin and establish ultrastructurally intact 
nodes of Ranvier [62]. $\mathrm{Na}_{\mathrm{v}} 1.6$ is the predominant $\mathrm{Na}_{\mathrm{v}}$ at

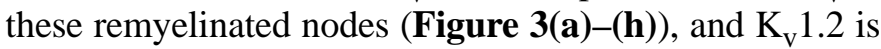
aggregated in remyelinated juxtaparanodal domains. These observations, coupled with improved conduction velocity of the remyelinated axons (Figure 3(i)-(m)), indicate that a relatively mature pattern of ion channel organization is recapitulated within spinal cord axons remyelinated by transplanted OECs.

\section{TRANSPLANTATION OF OLFACTORY ENSHEATHING CELLS INTO EXPERIMENTAL SPINAL CORD TRANSECTION LESIONS}

Local sprouting can occur after axonal transection in the mammalian spinal cord, but the axons do not regenerate for an appreciable distance. However, experimental approaches have been reported to improve elongative regeneration of axons in the transected mammalian spinal cord. These approaches include blockade of inhibitory proteins on glial cells and introduction of neurotrophic factor-enhanced peripheral nerve bridges. In a large number of recent studies, OECs have been transplanted into injured spinal cord and significant functional recovery has been reported [28-29,33,63]. The precise mechanisms accounting for this functional recovery are complex and include promotion of axonal regeneration, remyelination, neuroprotection, and induction of neovascularization. We should point out that in one study, functional improvement was not observed following OEC transplantation but was observed following Schwann cell transplantation [64]. Moreover, other investigators have not found unique migratory properties of OECs [65] and one report questioned the efficacy of transplantation of lamina propria into complete spinal cord transection [66].

OECs transplanted into the dorsal hemisected spinal cord survive and integrate into the lesion (Figure 4). Figure 4(a) shows a sagittal section of the spinal cord
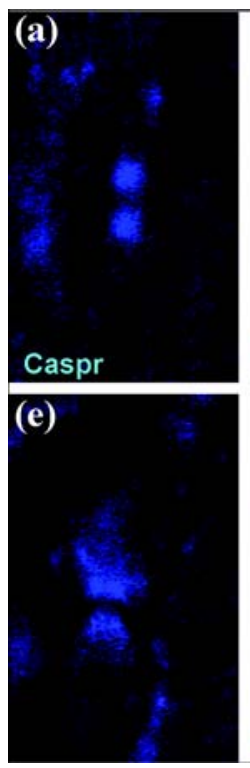
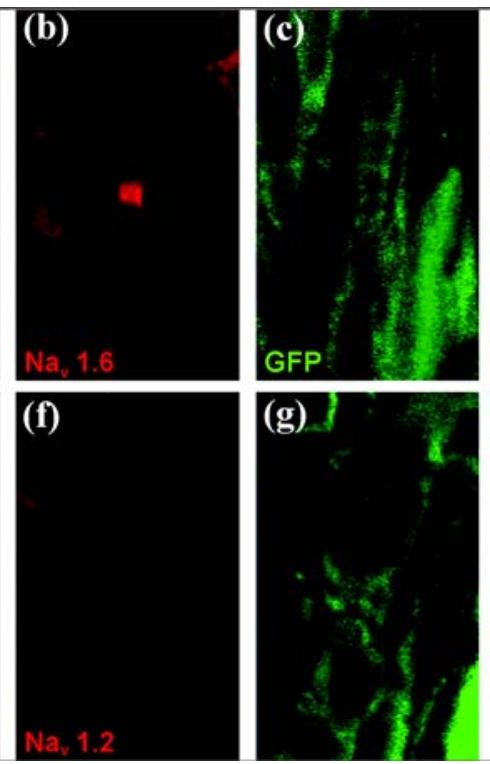
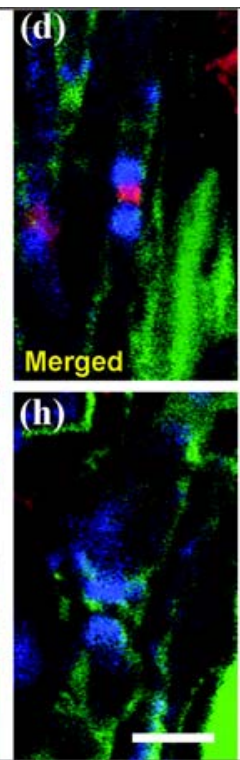

(i)

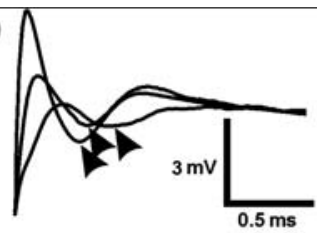

(k) (j)

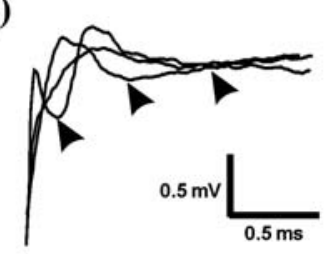

(m)

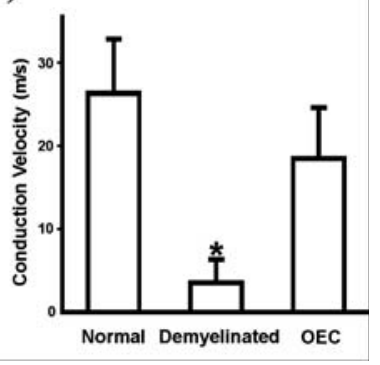

Figure 3.

Histological and electrophysiological evidence of mature node formation 3 weeks after olfactory ensheathing cell (OEC) transplantation into chemically demyelinated lesion. (a)-(h) Nodes of Ranvier associated with green fluorescent protein (GFP)-OECs (green) double-stained with contactin-associated protein (Caspr) (blue, stains in paranodal regions) and either (a)-(d) voltage-gated sodium channel ( $\mathrm{Na}_{\mathrm{v}}$ ) 1.6 (red), commonly associated with mature nodes, or (e)-(h) $\mathrm{Na}_{\mathrm{v}} 1.2$ (red), commonly associated with nonmyelinated axons or early stages in node formation. Merged images ((d) and (h)) show that $\mathrm{Na}_{\mathrm{v}} 1.6$ is clustered at Caspr-delimited nodes, while $\mathrm{Na}_{\mathrm{v}} 1.2$ is absent. (i)-(l) Compound action potentials recorded across lesioned area from (i) normal control spinal cord, (j) demyelinated lesion without cell transplantation, and (k)-(l) two OEC transplanted lesions. (m) Conduction velocities of normal, demyelinated only, and demyelinated and OEC-transplanted spinal cords $(n=6$ each group). Conduction velocities for demyelinated axons significantly differ from both normal control and OEC-transplanted spinal cords $\left({ }^{*} p<\right.$ 0.005). Scale bar is $10 \mu \mathrm{m}$ for all photographs. Modified from Sasaki M, Lankford KL, Zemedkun M, Kocsis JD. Identified olfactory ensheathing cells transplanted into the transected dorsal funiculus bridge the lesion and form myelin. J Neurosci. 2004;24(39):8485-93. [PMID: 15456822] 


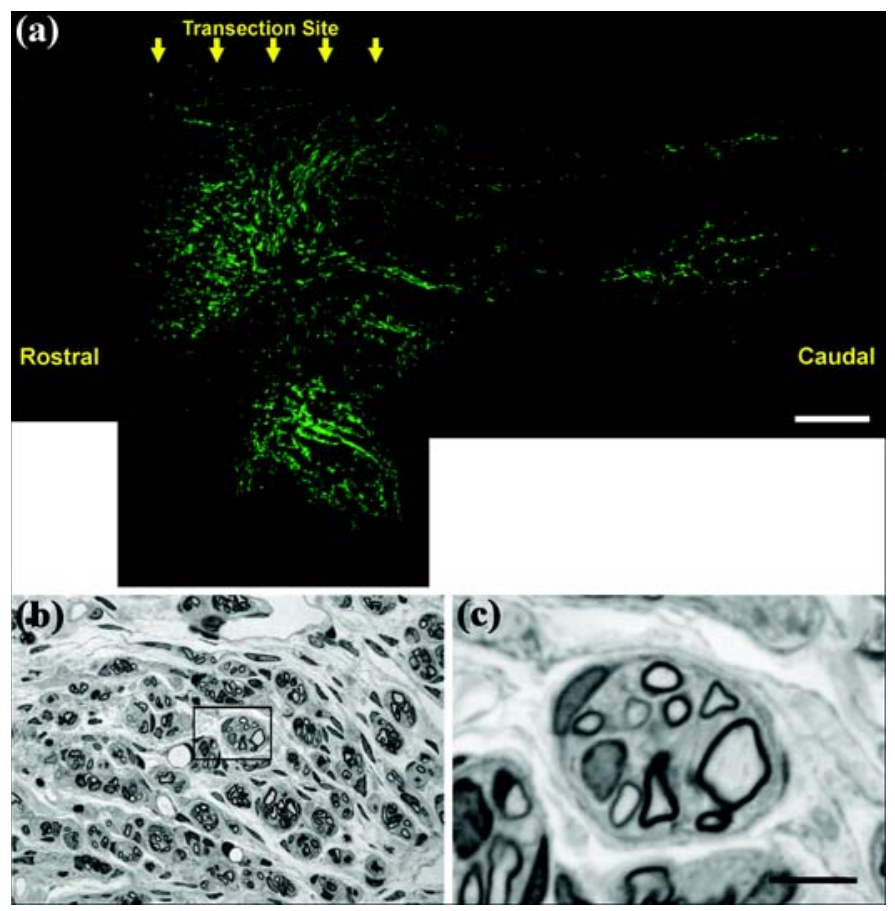

Figure 4.

Distribution and organization of olfactory ensheathing cells (OECs) transplanted into transection lesion. (a) Sagittal frozen section showing distribution of green fluorescent protein-OECs within and beyond transected lesion. (b)-(c) Semithin coronal plastic sections within lesioned area showing clusters of myelinated axons, which was characteristic of OECs transplanted in transected lesions. (b) Low magnification image showing many axon clusters. (c) Boxed area in (b) enlarged to show detail of individual axon cluster apparently surrounded by another cell. Scale bars: (a) $250 \mu \mathrm{m}$, (b) $30 \mu \mathrm{m}$, (c) $6 \mu \mathrm{m}$. Modified from Sasaki M, Lankford KL, Zemedkun M, Kocsis JD. Identified olfactory ensheathing cells transplanted into the transected dorsal funiculus bridge the lesion and form myelin. J Neurosci. 2004;24(39):8485-93. [PMID: 15456822]

spanning the transection site 4 weeks after transplantation of GFP-expressing OECs. Note that the green cells have integrated across the transection site (Figure 4(a)). Examination of the lesion site after transplantation in coronal section from semithin plastic embedded sections indicates groups of myelinated axons (Figure 4(b)). A higher power image (Figure 4(c)) shows that these groups of myelinated axons are surrounded by a cellular element. This configuration of myelinated regenerated axons inside of a cellular channel or bridge is unique to transplantation of OECs and is not observed after transplantation of Schwann cells [36].
Raisman proposes that two populations of cells are present in OEC preparations derived from the OB: a fibroblast-like cell, or A-cell, and a Schwannlike cell, or S-cell [35]. He proposes that the A-cell forms the surrounding cell and that the S-cells can form myelin on the regenerated axons. Moreover, the A-cell appears to form a channel across the lesion zone through which regenerating axons can grow. The myelin at this position in the lesion is primarily peripheral-like [36,63]. Endogenous Schwann cells can invade SCI sites and form myelin, and while OECs contribute to the remyelination, endogenous Schwann cells also likely contribute.

OECs can produce several molecules that may promote axonal regeneration and neuronal survival. These molecules include neurotrophic factors such as nerve growth factor (NGF), brain-derived neurotrophic factor (BDNF), and glial cell line-derived neurotrophic factor [20,67-69]. OECs have been shown to decrease spinal cord lesion size, possibly because of a local neuroprotective effect by neurotrophin release.

A recent study examined the effects of OEC transplantation into the dorsal transected spinal cord, which transects the dorsal corticospinal tract on apoptosis and neuronal death in the primary motor cortex (M1) [44]. Transection alone results in considerable apoptosis and atrophy of M1 pyramidal neurons [70]. We found that the number of apoptotic M1 neurons after corticospinal tract transection and OEC transplantation was reduced by about half at 1 week. Moreover, the number of surviving M1 pyramidal neurons was considerably increased at 4 weeks posttransection if OECs were transplanted. Interestingly, BDNF levels in the spinal cord transplant site were increased, suggesting that BDNF may have played a neuroprotective role in preserving the transected cortical neurons [44]. Thus, in addition to axonal regeneration and remyelination, OECs may provide trophic support for both local and remote neuronal survival.

\section{POSSIBLE CONTRIBUTION OF OLFACTORY ENSHEATHING CELL TRANSPLANTATION TO PERIPHERAL NERVE REPAIR}

Unlike the CNS, regeneration can occur in the PNS. The Schwann cells in the distal segment of a cut nerve dissociate from the degenerating axons, upregulate p75NGFR, and express NGF [71]. The axons in the proximal nerve stump sprout and regenerate through Schwann 
cell-enriched basal lamina tubes and can reestablish functional connections in peripheral targets such as skin and muscle; various degrees of functional recovery can occur. However, issues such as navigation of axons across a complex nerve injury site and appropriate targeting to peripheral end structures are major clinical concerns.

OEC transplantation has also been considered for enhancing repair of peripheral nerve fibers. The rationale is that OECs may provide a scaffold for the regenerating axons, as well as trophic factors and directional cues [72]. Transplantation of OECs into axotomized facial nerve has been shown to enhance axonal sprouting [72-73] and promote the recovery of vibrissae motor performance [74]. Choi and Raisman demonstrated that the rate of eye closure increased after OEC transplantation in a facial nerve lesion model but that aberrant nerve branching was unchanged [75]. Schwann cells [76] and OECs [77] transplanted into transected sciatic nerve integrate into the injury site and form peripheral myelin on the regenerated axons. Moreover, the nodes of Ranvier of the regenerated axons myelinated by the transplanted cells express the appropriate sodium channel $\left(\mathrm{Na}_{\mathrm{v}} 1.6\right)$. Whether these engrafted cells accelerate or improve functional outcome after nerve injury is yet to be determined [77].

\section{ONGOING CLINICAL STUDIES USING OLFACTORY ENSHEATHING CELLS IN SPINAL CORD INJURY}

Several groups are conducting or planning clinical studies on OEC transplantation into patients with SCI [78-80]. Feron and colleagues have conducted a phase I safety study using suspensions of OECs cultured from biopsied tissue from the patients' own OM, thus reducing immune rejection [81]. They reported no adverse effects at 12 months posttransplantation but no neurological improvement. Lima and colleagues (Egas Moniz Hospital, Lisbon, Portugal) described a treatment in which they packed the cavity of the SCI site with acutely prepared minced OM tissue, which includes many cell types, including stem cells and OECs. They reported that the OM autograft transplantation was safe and potentially beneficial, but efficacy was not clearly established [82].

In studies by Huang and colleagues (Chaoyang Hospital, Beijing, China), several hundred patients have received transplants of cultures from human embryonic OBs obtained from 14 to 16 fetuses [83-85]. Some func- tional improvement was reported as early as 1 day after transplantation. Surely such an early effect is not the result of axonal regeneration or remyelination. One should note that the Lima et al. and Huang et al. studies did not include control studies [78,84].

Dobkin et al. independently studied seven patients with chronic SCI who were undergoing surgery by the Huang group in Beijing [84]. For assessment, they used magnetic resonance imaging, the protocol of the American Spinal Injury Association for change in disability, and a detailed history of the perioperative course. They concluded that the phenotype and fate of the cells referred to as OECs are unknown and that perioperative morbidity and lack of functional benefit were very serious shortcomings. They also emphasized a lack of attempt to meet international standards for safety and efficacy. On the basis of their observations, they urge physicians not to recommend this procedure to patients at this time.

Assessing the efficacy of therapeutic interventions in SCI including cell therapy approaches is difficult because some "spontaneous" functional improvement occurs in most patients with SCI [86]. Moreover, the surgical intervention necessary for transplanting cells can alone lead to modest functional improvement. Issues related to assessment methods of patients with SCI in clinical studies are currently being discussed, with an emphasis on assessing the degree of an individual patient's functional recovery [87]. Clearly, the complexity of SCI and the difficulty in accurately assessing functional recovery will be challenges for all interventional clinical studies for SCI.

While reconstruction of appropriate spinal circuits by cell-based therapies is the ultimate long-term goal of cell transplantation research, laboratory work to date suggests that more immediate therapeutic benefits will come from neuroprotective effects and remyelination. Moreover, the most extensive functional recovery in animal models of SCI with cell transplantation is for treatment of acute and subacute SCI. Early intervention may reduce scar formation and secondary cell death by causing the release of appropriate trophic factors by engrafted cells. Moreover, angiogenic factors released by transplanted cells could cause neovascularization, which would be critical for tissue preservation. Some demyelination in patients with long-term (a decade) SCI has been reported [88]. If longterm SCI patients preserve some long tract axons in the spinal cord that were demyelinated, remyelination of these tracts by cell transplantation could cause some functional improvement. An important remaining challenge 
for cell-based therapies in SCI is determination of the optimal cell type, method of delivery, and timing of cellular intervention.

\section{CONCLUSIONS}

OECs are unique glial cells that support axonal growth of olfactory nerve fibers into the OB of the CNS. They form cellular "channels" through which axons can grow, produce a number of neurotrophic factors, and under special conditions, can form peripheral-like myelin on axons. In experimental SCI models, including transection and contusion injuries, transplantation of OECs within a week after injury can improve functional recovery. Some functional improvement was reported when OECs were transplanted several months after injury. While the precise mechanisms for the therapeutic effects of OECs are not fully understood, several studies indicate that facilitation of axonal regrowth, remyelination, and neuroprotection may contribute. Clinical studies using OECs in SCI are ongoing, but efficacy has not as yet been established in these initial studies [84]. To date, the clinical studies have been performed in patients with chronic SCI, but experimental studies suggest that OECs are most effective in acute and possibly subacute SCI. Evaluating the therapeutic potential of OECs in acute SCI will be important in future clinical studies.

\section{ACKNOWLEDGMENTS}

This material was based on work supported by the Medical and Rehabilitation Research and Development Services of the Department of Veterans Affairs, the National Institute of Neurological Disorders and Stroke (grant NS073432), and the National Multiple Sclerosis Society (grants RG 2135 and CA 1009A10).

The authors have declared that no competing interests exist.

\section{REFERENCES}

1. Jackson AB, Dijkers M, Devivo MJ, Poczatek RB. A demographic profile of new traumatic spinal cord injuries: Change and stability over 30 years. Arch Phys Med Rehabil. 2004;85(11):1740-48. [PMID: 15520968]
2. Reier PJ. Cellular transplantation strategies for spinal cord injury and translational neurobiology. NeuroRx. 2004;1(4): 424-51. [PMID: 15717046]

3. Radtke C, Spies M, Sasaki M, Vogt PM, Kocsis JD. Demyelinating diseases and potential repair strategies. Int J Dev Neurosci. 2007;25(3):149-53. [PMID: 17408905]

4. Gage FH, Ray J, Fisher LJ. Isolation, characterization, and use of stem cells from the CNS. Annu Rev Neurosci. 1995; 18:159-92. [PMID: 7605059]

5. Gritti A, Frolichsthal-Schoeller P, Galli R, Parati EA, Cova L, Pagano SF, Bjornson CR, Vescovi AL. Epidermal and fibroblast growth factors behave as mitogenic regulators for a single multipotent stem cell-like population from the subventricular region of the adult mouse forebrain. J Neurosci. 1999;19(9):3287-97. [PMID: 10212288]

6. Rao MS. Multipotent and restricted precursors in the central nervous system. Anat Rec. 1999;257(4):137-48. [PMID: 10467245]

7. Reynolds BA, Weiss S. Generation of neurons and astrocytes from isolated cells of the adult mammalian central nervous system. Science. 1992;255(5052):1707-10. [PMID: 1553558]

8. Shihabuddin LS, Hertz JA, Holets VR, Whittemore SR. The adult CNS retains the potential to direct region-specific differentiation of a transplanted neuronal precursor cell line. J Neurosci. 1995;15(10):6666-78. [PMID: 7472427]

9. Akiyama Y, Honmou O, Kato T, Uede T, Hashi K, Kocsis JD. Transplantation of clonal neural precursor cells derived from adult human brain establishes functional peripheral myelin in the rat spinal cord. Exp Neurol. 2001;167(1):27-39. [PMID: 11161590]

10. Steindler DA, Pincus DW. Stem cells and neuropoiesis in the adult human brain. Lancet. 2002;359(9311):1047-54. [PMID: 11937201]

11. Vescovi AL, Gritti A, Galli R, Parati EA. Isolation and intracerebral grafting of nontransformed multipotential embryonic human CNS stem cells. J Neurotrauma. 1999; 16(8):689-93. [PMID: 10511241]

12. Oka S, Honmou O, Akiyama Y, Sasaki M, Houkin K, Hashi K, Kocsis JD. Autologous transplantation of expanded neural precursor cells into the demyelinated monkey spinal cord. Brain Res. 2004;1030(1):94-102. [PMID: 15567341]

13. Kopen GC, Prockop DJ, Phinney DG. Marrow stromal cells migrate throughout forebrain and cerebellum, and they differentiate into astrocytes after injection into neonatal mouse brains. Proc Natl Acad Sci U S A. 1999;96(19): 10711-16. [PMID: 10485891]

14. Akiyama Y, Radtke C, Honmou O, Kocsis JD. Remyelination of the spinal cord following intravenous delivery of bone marrow cells. Glia. 2002;39(3):229-36. [PMID: 12203389] 
15. Barber PC, Lindsay RM. Schwann cells of the olfactory nerves contain glial fibrillary acidic protein and resemble astrocytes. Neuroscience. 1982;7(12):3077-90. [PMID: 6761599]

16. Farbman AI. Olfactory neurogenesis: Genetic or environmental controls? Trends Neurosci. 1990;13(9):362-65. [PMID: 1699323]

17. Graziadei PP, Graziadei GA. Neurogenesis and neuron regeneration in the olfactory system of mammals. I. Morphological aspects of differentiation and structural organization of the olfactory sensory neurons. J Neurocytol. 1979; 8(1):1-18. [PMID: 438867]

18. Doucette R. Glial influences on axonal growth in the primary olfactory system. Glia. 1990;3(6):433-49. [PMID: 2148546]

19. Raisman G. Specialized neuroglial arrangement may explain the capacity of vomeronasal axons to reinnervate central neurons. Neuroscience. 1985;14(1):237-54. [PMID: 3974880]

20. Ramon-Cueto A, Avila J. Olfactory ensheathing glia: Properties and function. Brain Res Bull. 1998;46(3):175-87. [PMID: 9667810]

21. Luskin MB, Zigova T, Soteres BJ, Stewart RR. Neuronal progenitor cells derived from the anterior subventricular zone of the neonatal rat forebrain continue to proliferate in vitro and express a neuronal phenotype. Mol Cell Neurosci. 1997;8(5):351-66. [PMID: 9073397]

22. Bunge RP. Glial cells and the central myelin sheath. Physiol Rev. 1968;48(1):197-251. [PMID: 4866614]

23. Schwob JE, Szumowski KE, Stasky AA. Olfactory sensory neurons are trophically dependent on the olfactory bulb for their prolonged survival. J Neurosci. 1992;12(10):3896-3919. [PMID: 1403089]

24. Valverde F, Lopez-Mascaraque L. Neuroglial arrangements in the olfactory glomeruli of the hedgehog. J Comp Neurol. 1991;307(4):658-74. [PMID: 1714466]

25. Barnett SC, Roskams AJ. Olfactory ensheathing cells. Isolation and culture from the rat olfactory bulb. Methods Mol Biol. 2002;198:41-48. [PMID: 11951639]

26. Chuah MI, Au C. Cultures of ensheathing cells from neonatal rat olfactory bulbs. Brain Res. 1993;601(1-2):213-20. [PMID: 8431768]

27. Au E, Roskams AJ. Olfactory ensheathing cells of the lamina propria in vivo and in vitro. Glia. 2003;41(3):224-36. [PMID: 12528178]

28. Lu J, Feron F, Ho SM, Mackay-Sim A, Waite PM. Transplantation of nasal olfactory tissue promotes partial recovery in paraplegic adult rats. Brain Res. 2001;889(1-2):344-57. [PMID: 11166728]

29. Ramon-Cueto A, Cordero MI, Santos-Benito FF, Avila J. Functional recovery of paraplegic rats and motor axon regeneration in their spinal cords by olfactory ensheathing glia. Neuron. 2000;25(2):425-35. [PMID: 10719896$]$
30. Doucette R. Glial cells in the nerve fiber layer of the main olfactory bulb of embryonic and adult mammals. Microscopy Res Tech. 1993;24(2):113-30. [PMID: 8457724]

31. Doucette R. Glial progenitor cells of the nerve fiber layer of the olfactory bulb: Effect of astrocyte growth media. J Neurosci Res. 1993;35(3):274-87. [PMID: 8350389]

32. Barnett SC, Hutchins AM, Noble M. Purification of olfactory nerve ensheathing cells from the olfactory bulb. Dev Biol. 1993;155(2):337-50. [PMID: 7679359]

33. Ramon-Cueto A, Nieto-Sampedro M. Regeneration into the spinal cord of transected dorsal root axons is promoted by ensheathing glia transplants. Exp Neurol. 1994;127(2): 232-44. [PMID: 8033963]

34. Gudino-Cabrera G, Nieto-Sampedro M. Schwann-like macroglia in adult rat brain. Glia. 2000;30(1):49-63. [PMID: 10696144]

35. Raisman G. Olfactory ensheathing cells-Another miracle cure for spinal cord injury? Nat Rev Neurosci. 2001;2(5): 369-75. [PMID: 11331921]

36. Imaizumi T, Lankford KL, Burton WV, Fodor WL, Kocsis JD. Xenotransplantation of transgenic pig olfactory ensheathing cells promotes axonal regeneration in rat spinal cord. Nat Biotechnol. 2000;18(9):949-53. [PMID: 10973214]

37. Imaizumi T, Lankford KL, Waxman SG, Greer CA, Kocsis JD. Transplanted olfactory ensheathing cells remyelinate and enhance axonal conduction in the demyelinated dorsal columns of the rat spinal cord. J Neurosci. 1998;18(16): 6176-85. [PMID: 9698311]

38. Franklin RJ, Barnett SC. Olfactory ensheathing cells and CNS regeneration: The sweet smell of success? Neuron. 2000;28(1):15-18. [PMID: 11086978]

39. Franklin RJ, Gilson JM, Franceschini IA, Barnett SC. Schwann cell-like myelination following transplantation of an olfactory bulb-ensheathing cell line into areas of demyelination in the adult CNS. Glia. 1996;17(3):217-24. [PMID: 8840163]

40. Barnett SC, Alexander CL, Iwashita Y, Gilson JM, Crowther J, Clark L, Dunn LT, Papanastassiou V, Kennedy PG, Franklin RJ. Identification of a human olfactory ensheathing cell that can effect transplant-mediated remyelination of demyelinated CNS axons. Brain. 2000;123(Pt 8):1581-88.

[PMID: 10908188]

41. Kato T, Honmou O, Uede T, Hashi K, Kocsis JD. Transplantation of human olfactory ensheathing cells elicits remyelination of demyelinated rat spinal cord. Glia. 2000; 30(3):209-18. [PMID: 10756071]

42. Radtke C, Akiyama Y, Brokaw J, Lankford KL, Wewetzer K, Fodor WL, Kocsis JD. Remyelination of the nonhuman primate spinal cord by transplantation of H-transferase transgenic adult pig olfactory ensheathing cells. FASEB J. 2004; 18(2):335-37. [PMID: 14657003] 
43. Sasaki M, Lankford KL, Zemedkun M, Kocsis JD. Identified olfactory ensheathing cells transplanted into the transected dorsal funiculus bridge the lesion and form myelin. J Neurosci. 2004;24(39):8485-93. [PMID: 15456822]

44. Sasaki M, Hains BC, Lankford KL, Waxman SG, Kocsis JD. Protection of corticospinal tract neurons after dorsal spinal cord transection and engraftment of olfactory ensheathing cells. Glia. 2006;53(4):352-59. [PMID: 16288464]

45. Rizek PN, Kawaja MD. Cultures of rat olfactory ensheathing cells are contaminated with Schwann cells. Neuroreport. 2006;17(5):459-62. [PMID: 16543806]

46. Boyd JG, Jahed A, McDonald TG, Krol KM, Van Eyk JE, Doucette R, Kawaja MD. Proteomic evaluation reveals that olfactory ensheathing cells but not Schwann cells express calponin. Glia. 2006;53(4):434-40. [PMID: 16345031]

47. Ibanez C, Ito D, Zawadzka M, Jeffery ND, Franklin RJ. Calponin is expressed by fibroblasts and meningeal cells but not olfactory ensheathing cells in the adult peripheral olfactory system. Glia. 2007;55(2):144-51. [PMID: 17078028]

48. Kocsis JD. Restoration of function by glial cell transplantation into demyelinated spinal cord. J Neurotrauma. 1999; 16(8):695-703. [PMID: 10511242]

49. Girault JA, Peles E. Development of nodes of Ranvier. Curr Opin Neurobiol. 2002;12(5):476-85. [PMID: 12367625]

50. Peles E, Salzer JL. Molecular domains of myelinated axons. Curr Opin Neurobiol. 2000;10(5):558-65. [PMID: 11084317]

51. Rasband MN, Trimmer JS. Developmental clustering of ion channels at and near the node of Ranvier. Dev Biol. 2001;236(1):5-16. [PMID: 11456440]

52. Goldin AL, Barchi RL, Caldwell JH, Hofmann F, Howe JR, Hunter JC, Kallen RG, Mandel G, Meisler MH, Netter YB, Noda M, Tamkun MM, Waxman SG, Wood JN, Catterall WA. Nomenclature of voltage-gated sodium channels. Neuron. 2000;28(2):365-68. [PMID: 11144347]

53. Boiko T, Rasband MN, Levinson SR, Caldwell JH, Mandel G, Trimmer JS, Matthews G. Compact myelin dictates the differential targeting of two sodium channel isoforms in the same axon. Neuron. 2001;30(1):91-104. [PMID: 11343647]

54. Caldwell JH, Schaller KL, Lasher RS, Peles E, Levinson SR. Sodium channel $\mathrm{Na}(\mathrm{v}) 1.6$ is localized at nodes of Ranvier, dendrites, and synapses. Proc Natl Acad Sci U S A. 2000;97(10):5616-20. [PMID: 10779552]

55. Jenkins SM, Bennett V. Developing nodes of Ranvier are defined by ankyrin-G clustering and are independent of paranodal axoglial adhesion. Proc Natl Acad Sci U S A. 2002;99(4):2303-8. [PMID: 11842202]

56. Kaplan MR, Cho MH, Ullian EM, Isom LL, Levinson SR, Barres BA. Differential control of clustering of the sodium channels $\mathrm{Na}(\mathrm{v}) 1.2$ and $\mathrm{Na}(\mathrm{v}) 1.6$ at developing CNS nodes of Ranvier. Neuron. 2001;30(1):105-19. [PMID: 11343648$]$

57. Rios JC, Rubin M, St Martin M, Downey RT, Einheber S, Rosenbluth J, Levinson SR, Bhat M, Salzer JL. Paranodal interactions regulate expression of sodium channel subtypes and provide a diffusion barrier for the node of Ranvier. J Neurosci. 2003;23(18):7001-11. [PMID: 12904461]

58. Rasband MN, Peles E, Trimmer JS, Levinson SR, Lux SE, Shrager P. Dependence of nodal sodium channel clustering on paranodal axoglial contact in the developing CNS. J Neurosci. 1999;19(17):7516-28. [PMID: 10460258]

59. Vabnick I, Messing A, Chiu SY, Levinson SR, Schachner M, Roder J, Li C, Novakovic S, Shrager P. Sodium channel distribution in axons of hypomyelinated and MAG null mutant mice. J Neurosci Res. 1997;50(2):321-36.

[PMID: 9373041]

60. Kaplan MR, Meyer-Franke A, Lambert S, Bennett V, Duncan ID, Levinson SR, Barres BA. Induction of sodium channel clustering by oligodendrocytes. Nature. 1997;386(6626): 724-28. [PMID: 9109490]

61. Eshed Y, Feinberg K, Poliak S, Sabanay H, Sariq-Nadir O, Spiegel I, Bermingham JR Jr, Peles E. Gliomedin mediates Schwann cell-axon interaction and the molecular assembly of the nodes of Ranvier. Neuron. 2005;47(2):215-29. [PMID: 16039564]

62. Sasaki M, Black JA, Lankford KL, Tokuno HA, Waxman SG, Kocsis JD. Molecular reconstruction of nodes of Ranvier after remyelination by transplanted olfactory ensheathing cells in the demyelinated spinal cord. J Neurosci. 2006; 26(6):1803-12. [PMID: 16467529]

63. Li Y, Field PM, Raisman G. Repair of adult rat corticospinal tract by transplants of olfactory ensheathing cells. Science. 1997;277(5334):2000-2002. [PMID: 9302296]

64. Takami T, Oudega M, Bates ML, Wood PM, Kleitman N, Bunge MB. Schwann cell but not olfactory ensheathing glia transplants improve hindlimb locomotor performance in the moderately contused adult rat thoracic spinal cord. J Neurosci. 2002;22(15):6670-81. [PMID: 12151546]

65. Lu P, Yang H, Culbertson M, Graham L, Roskams AJ, Tuszynski MH. Olfactory ensheathing cells do not exhibit unique migratory or axonal growth-promoting properties after spinal cord injury. J Neurosci. 2006;26(43):11120-30. [PMID: 17065452]

66. Steward O, Sharp K, Selvan G, Hadden A, Hofstadter M, Au E, Roskams J. A re-assessment of the consequences of delayed transplantation of olfactory lamina propria following complete spinal cord transection in rats. Exp Neurol. 2006;198(2):483-99. [PMID: 16494866]

67. Franceschini IA, Barnett SC. Low-affinity NGF-receptor and E-N-CAM expression define two types of olfactory nerve ensheathing cells that share a common lineage. Dev Biol. 1996;173(1):327-43. [PMID: 8575633]

68. Ronnett GV, Hester LD, Snyder SH. Primary culture of neonatal rat olfactory neurons. J Neurosci. 1991;11(5):1243-55. [PMID: 1851216$]$ 
69. Wewetzer K, Grothe C, Claus P. In vitro expression and regulation of ciliary neurotrophic factor and its alpha receptor subunit in neonatal rat olfactory ensheathing cells. Neurosci Lett. 2001;306(3):165-68. [PMID: 11406321]

70. Hains BC, Black JA, Waxman SG. Primary cortical motor neurons undergo apoptosis after axotomizing spinal cord injury. J Compar Neurol. 2003;462(3):328-41. [PMID: 12794736]

71. Johnson EM Jr, Taniuchi M, DiStefano PS. Expression and possible function of nerve growth factor receptors on Schwann cells. Trends Neurosci. 1988;11(7):299-304. [PMID: 2465632]

72. Deumens R, Koopmans GC, Honig WM, Hamers FP, Maquet V, Jerome R, Steinbusch HW, Joosten EA. Olfactory ensheathing cells, olfactory nerve fibroblasts and biomatrices to promote long-distance axon regrowth and functional recovery in the dorsally hemisected adult rat spinal cord. Exp Neurol. 2006;200(1):89-103.

[PMID: 16527274$]$

73. Guntinas-Lichius O, Angelov DN, Tomov TL, Dramiga J, Neiss WF, Wewetzer K. Transplantation of olfactory ensheathing cells stimulates the collateral sprouting from axotomized adult rat facial motoneurons. Exp Neurol. 2001; 172(1):70-80. [PMID: 11681841]

74. Guntinas-Lichius O, Wewetzer K, Tomov TL, Azzolin N, Kazemi S, Streppel M, Neiss WF, Angelov DN. Transplantation of olfactory mucosa minimizes axonal branching and promotes the recovery of vibrissae motor performance after facial nerve repair in rats. J Neurosci. 2002;22(16):7121-31. [PMID: 12177208]

75. Choi D, Raisman G. Disorganization of the facial nucleus after nerve lesioning and regeneration in the rat: Effects of transplanting candidate reparative cells to the site of injury. Neurosurgery. 2005;56(5):1093-1100. [PMID: 15854259]

76. Radtke C, Akiyama Y, Lankford KL, Vogt PM, Krause DS, Kocsis JD. Integration of engrafted Schwann cells into injured peripheral nerve: Axonal association and nodal formation on regenerated axons. Neurosci Lett. 2005;387(2): 85-89. [PMID: 16084645]

77. Dombrowski MA, Sasaki M, Lankford KL, Kocsis JD, Radtke C. Myelination and nodal formation of regenerated peripheral nerve fibers following transplantation of acutely prepared olfactory ensheathing cells. Brain Res. 2006;1125(1):1-8. [PMID: 17112480]

78. Ibrahim A, Li Y, Li D, Raisman G, El Masry WS. Olfactory ensheathing cells: Ripples of an incoming tide? Lancet Neurol. 2006;5(5):453-57. [PMID: 16632316]
79. Senior K. Olfactory ensheathing cells to be used in spinalcord repair trial. Lancet Neurol. 2002;1(5):269.

[PMID: 12849411]

80. Watts J. Controversy in China. Lancet. 2005;365(9454): 109-10. [PMID: 15643702]

81. Feron F, Perry C, Cochrane J, Licina P, Nowitzke A, Urquhart S, Geraghty T, Mackay-Sim A. Autologous olfactory ensheathing cell transplantation in human spinal cord injury. Brain. 2005;128(Pt 12):2951-60. [PMID: 16219671]

82. Lima C, Pratas-Vital J, Escada P, Hasse-Ferreira A, Capucho C, Peduzzi JD. Olfactory mucosa autografts in human spinal cord injury: A pilot clinical study. J Spinal Cord Med. 2006;29(3):191-206. [PMID: 16859223]

83. Curt A, Dietz V. Controversial treatments for spinal-cord injuries. Lancet. 2005;365(9462):841. [PMID: 15752519]

84. Dobkin BH, Curt A, Guest J. Cellular transplants in China: Observational study from the largest human experiment in chronic spinal cord injury. Neurorehabil Neural Rep. 2006; 20(1):5-13. [PMID: 16467274

85. Huang H, Chen L, Wang H, Xiu B, Li B, Wang R, Zhang J, Zhang F, Gu Z, Li Y, Song Y, Hao W, Pang S, Sun J. Influence of patients' age on functional recovery after transplantation of olfactory ensheathing cells into injured spinal cord injury. Chinese Med J (Engl). 2003;116(10):1488-91. [PMID: 14570607]

86. Fawcett JW, Curt A, Steeves JD, Coleman WP, Tuszynski MH, Lammertse D, Bartlett PF, Blight AR, Dietz V, Ditunno J, Dobkin BH, Havton LA, Ellaway PH, Fehlings MG, Privat A, Grossman R, Guest JD, Kleitman N, Nakamura M, Gaviria M, Short D. Guidelines for the conduct of clinical trials for spinal cord injury as developed by the ICCP panel: Spontaneous recovery after spinal cord injury and statistical power needed for therapeutic clinical trials. Spinal Cord. 2007;45(3):190-205. [PMID: 17179973$]$

87. Curt A, Schwab ME, Dietz V. Providing the clinical basis for new interventional therapies: Refined diagnosis and assessment of recovery after spinal cord injury. Spinal Cord. 2004;42(1):1-6. [PMID: 14713937]

88. Guest JD, Hiester ED, Bunge RP. Demyelination and Schwann cell responses adjacent to injury epicenter cavities following chronic human spinal cord injury. Exp Neurol. 2005;192(2):384-93. [PMID: 15755556$]$

Submitted for publication March 23, 2007. Accepted in revised form June 26, 2007. 